\title{
ESTIMATION OF THE MECHANICAL PROPERTIES OF WOOD FROM Eucalyptus urophylla USING NEAR INFRARED SPECTROSCOPY
}

\author{
Carlos Rogério Andrade ${ }^{1}$, Paulo Fernando Trugilho², Alfredo Napoli ${ }^{3}$, \\ Renato da Silva Vieira ${ }^{4}$, José Tarcísio Lima², Leonardo Chagas de Sousa ${ }^{5}$
}

(received: October 9, 2009; accepted: April 30, 2010)

\begin{abstract}
Mechanical properties studies of wood usually involve destructive wood assessments, with time-consuming tests that use large amounts of resource (wood). Although this is not a limiting factor, it could be attenuated by the use of a nondestructive technique known as near infrared spectroscopy (NIRS). This technique has been applied to evaluate compounds containing $\mathrm{C}$ - $\mathrm{H}$, $\mathrm{N}-\mathrm{H}, \mathrm{S}-\mathrm{H}$ or O-H bonds, and involves quick analyses and can be applied to process control tasks. The objective of this work is to use the NIRS technique to obtain calibrations for mechanical properties of Eucalyptus sp. wood. A natural E. urophylla hybrid at age 7 was used as obtained from V\&M Florestal crops. Spectra were measured directly in solid wood (radial, tangential and transverse faces) and in ground wood, in diffuse reflectance mode, using a Bruker spectrometer in the 800 to 1,500 $\mathrm{nm}$ range. The NIRS technique proved suitable to estimate modulus of elasticity in solid wood, with values $\mathrm{r}=0.91$ and RPD=2.6, and in ground wood, with values $r=0.87$ and $R P D=2.0$. Modulus of rupture and compressive strength presented $r$ values below 0.9 . First and second derivative pretreatments provided a slight increase in correlation values for the properties in question. Calibrations for different plank faces did not present a defined variation pattern. Solid wood and ground wood presented similar correlation values for all properties.
\end{abstract}

Key words: NIRS, Eucalyptus, characteristics.

\section{ESTIMATIVA DE PROPRIEDADES MECÂNICAS DA MADEIRA DE Eucalyptus urophylla USANDO A ESPECTROSCOPIA NO INFRAVERMELHO PRÓXIMO}

\begin{abstract}
RESUMO: O estudo das propriedades mecânicas da madeira comumente é realizado por meio de uma avaliação destrutiva na madeira demandando um extenso tempo para realização dos testes e com grande uso de recursos (madeira). Esse fator, embora não seja limitante para a realização dos ensaios poderia ser amenizado com o uso de uma técnica não-destrutiva como a espectroscopia no infravermelho próximo (NIRS). Essa técnica vem sendo aplicada na avaliação de compostos que contenham ligações $C$ - $H$, $N$ - $H$, $\mathrm{S}-\mathrm{H}$ ou $\mathrm{O}-\mathrm{H}$, apresenta rapidez nas análises e pode ser aplicada no controle de processos. $\mathrm{O}$ objetivo, neste trabalho, foi utilizar a técnica NIRS para obter calibrações para as propriedades mecânicas da madeira de Eucalyptus sp. Foi utilizado um híbrido natural de E. urophylla com 7 anos, da empresa V\&M Florestal. Os espectros foram medidos diretamente sobre madeira sólida (faces radial, tangencial e transversal) e moída, em modo de reflexão difusa, utilizando-se um espectrômetro Bruker na gama de 800 a $1500 \mathrm{~nm}$. A técnica NIRS se mostrou adequada para estimar o módulo de elasticidade obtido na madeira sólida com $r=0,91$ e RPD = 2,6 e moída com $r=0,87$ e $R P D=2,0$. O módulo de ruptura e a resistência a compressão apresentaram $r$ abaixo de 0,9. Os prétratamentos de primeira e segunda derivada proporcionaram um ligeiro aumento nos valores das correlações para as propriedades analisadas. Calibrações para as diferentes faces da madeira não apresentaram padrão de variação definido. Madeira sólida e moída apresentaram valores de correlação semelhantes para todas as propriedades.
\end{abstract}

Palavras-chave: NIRS, eucalipto, características.

\section{INTRODUCTION}

Properties relating to wood resistance include bend strength, also known as modulus of rupture, compressive strength, tensile strength, shear strength, stiffness, among others. And properties relating to wood elasticity include modulus of elasticity, Poisson coefficient, plasticity and resilience (KOLLMANN \& CÔTÉ JUNIOR 1968).

Strength in compression parallel to grain is the maximum load in the direction of the length a sample is

${ }^{1}$ Forest Engineer, Assistant Professor - Universidade Federal de Goiás, Campus Jataí - Unidade Jatobá - Rodovia BR 364, Km 192, nº 3800 - Parque Industrial - Cx. P. 03 - 75801-615 - Jataí, GO - cra.florestal@ yahoo.com.br

${ }^{2}$ Forest Engineer, Dr. Professor of Forest Science - Departamento de Ciências Florestais - Universidade Federal de Lavras - Cx. P. 3037 37200-000 - Lavras, MG - trugilho@dcf.ufla.br, jtlima@dcf.ufla.br

${ }^{3}$ Dr. Researcher with CIRAD - BIOS Department - TA A-39 - Genetic diversity and breeding of forest species - 73 rue Jean-François Breton - 34398 - Montpellier, France - alfredo.napoli@cirad.fr

${ }^{4}$ Forest Engineer, Dr. Professor of Wood Science and Technology - Universidade Federal do Tocantins - Rua Badejós, Chácaras 69/72, Lote 7 - Zona Rural - Cx. P. 66 - 77402-970 - Gurupi, TO - rsvieira@uft.edu.br

${ }^{5}$ Forest Engineer, Researcher with V\&M Florestal - Vallourec \& Mannesmann Tubes - Rua Honduras, 78, Bairro Leo Batista - 35790-000 Curvelo, MG - leonardo.chagas@vmtubes.com.br

Cerne, Lavras, v. 16, n. 3, p. 291-298, jul./set. 2010 
capable of sustaining (KOLLMANN \& COTÊ JÚNIOR 1968).

Modulus of rupture reflects a sample's ability to resist deformation when it is subjected to bending and is equivalent to the maximum moment shown by the sample (GREEN et al. 1999). Klock (2000) reports that high MOE values indicate a material's high strength and low deformation characteristics, which means it will qualify for structural works.

Typically, mechanical characterization of wood is done by destructive analysis of samples, using specific equipment that involves extensive, standard-based testing routines and capable of providing reliable results. However, this type of assessment requires a long lead time between preparing samples and arriving at final values for the relevant property.

Many researches have been conducted into alternative methods for fast and reliable wood characterization that, along with traditional methods, can result both in analysis quality and time gains. Among recently developed nondestructive methods for wood characterization is the near infrared spectroscopy technique (NIRS). According to Baillères et al. (2002), near infrared spectroscopy is a noninvasive analysis technique for organic materials, largely used by various manufacturing companies, forest sector included, in quality control and process monitoring tasks.

The above method can offer advantages in relation to traditional methods, as it is considered nondestructive and fast (one minute or less per sample) (PASQUINI 2003).

The basic principle is measuring absorbance spectra in the near infrared region of relevant samples, which then have their properties determined by traditional destructive analysis in a laboratory. NIR spectra are then subjected to regression analysis by the partial least square method (PLS), which is the most common method in calibration for model construction, using spectral signals (GELADI \& KOWALSKI 1986). Once the model has been calibrated for a given property, calibration should be tested for accuracy by a process known as validation. Model validation can be accomplished in two ways, namely external validation and cross validation (MARTENS \& NAES 1996).

External validation is considered simpler, yet it has the disadvantage of requiring another sample set, implying use of spectral measurement and conventional analysis and thus increasing time on task and procedure costs (SOTELO 2006). In cross validation, samples awaiting validation are the same samples used in the calibration test. Some samples are set aside, a model is constructed with the remaining samples and prediction is done in relation to samples initially set aside. This type of validation is recommended where a small number of samples is involved.

Several works have demonstrated the use potential of near infrared spectroscopy to determine wood properties, as, for example, studies developed by Fujimoto et al. (2008) and Schimleck et al. (1999) into density and also into strength and stiffness properties. Viana et al. (2009), by using NIRS technique for predicting the morfological characteristics and basic density, found interesting results. Hein (2010) found similar results for basic density in Eucalyptus hybrids. Studies were also conducted into mechanical strength (THUMM \& MEDER 2001). While studying E. grandis and E. urophylla, Hein et al. (2009) evaluated estimation of strength and elasticity in compression parallel to grain and found coefficients of determination of cross validation of 0.78 and 0.75 respectively. Ribeiro (2009) used the same technique to predict physical and mechanical properties of softwoods and hardwoods and found it to be a very effective technique, economically and practically speaking. Kelley et al. (2004) demonstrated the use potential of the NIRS technique to reliably predict mechanical properties of wood.

Being a noninvasive technique, the use of NIRS to investigate mechanical properties of wood is extremely promising, potentially translating as considerable gains in time and resources (wood).

With that said, Pasquini (2003) reports that where measurements are taken in diffuse reflectance mode, the NIRS technique can pose some problems, e.g. light dispersion and inaccuracies, due to differences in sample thickness. Therefore, using techniques that will help reduce, eliminate or standardize the effect of unwanted factors on spectra and yet maintain the spectroscopic information unchanged (SIESLER et al. 2002) is extremely important. Examples of such techniques include first and second derivative and multiplicative signal correction methods.

This research used the NIRS technique to estimate mechanical properties of wood from a Eucalyptus urophylla hybrid, as determined by static bending and compression parallel to grain testing.

\section{MATERIAL AND METHODS}

\subsection{Biological material and sampling}

An Eucalyptus urophylla hybrid aged 7 years was obtained from a commercial crop grown by V\&M Florestal, 
a company located in the municipality of Paraopeba, Minas Gerais state, Brazil.

Sampling was done using a single tree divided into lengthwise and widthwise sections. The stem was divided into 5 logs, each log being 5 meters long. Each log section was divided into planks, each plank being $150 \mathrm{~cm}$. This material was processed using a band saw and defect-free specimens were taken for static bending tests $(25 \times 25 \times 410$ $\mathrm{mm}$ in size) and compression parallel to grain tests $(25 \times 25 \mathrm{x}$ $100 \mathrm{~mm}$ in size) from the outer, central and inner portions of the plank, with well-oriented radial and tangential faces. Mechanical tests were performed in a universal testing machine EMIC DL 30000. Tests were run according to the ASTM D 143 - 94 standard (1997).

\subsection{NIR spectral acquisition}

For spectral acquisition, a Bruker MPA-R spectrometer was used, equipped with software Opus version 5.5. This equipment uses the Fourier transform and has an integrating sphere. Spectral acquisition was conducted in the 800 to $1,500 \mathrm{~nm}$ range, in diffuse reflectance mode, with spectral resolution of $8 \mathrm{~cm}^{-1}$ and 64 scans per reading. Readings were taken of solid wood spectra (on radial, tangential and transverse faces), then samples were ground and spectral readings were taken in ground wood retained in a 60-mesh sieve. The procedure of spectral acquisition is illustrated in Figure 1.
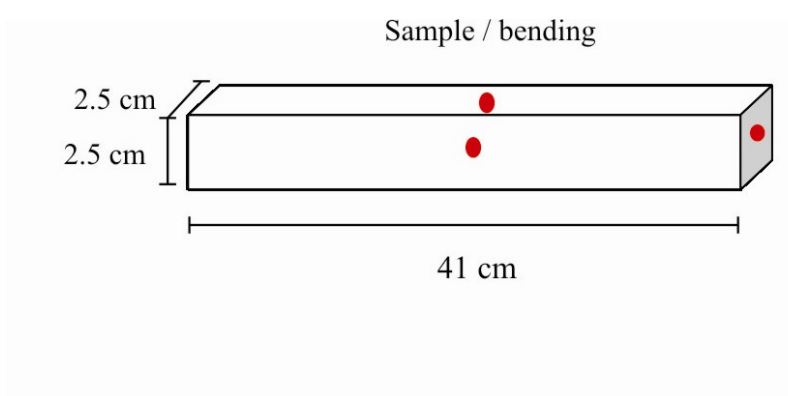

Sample / compression
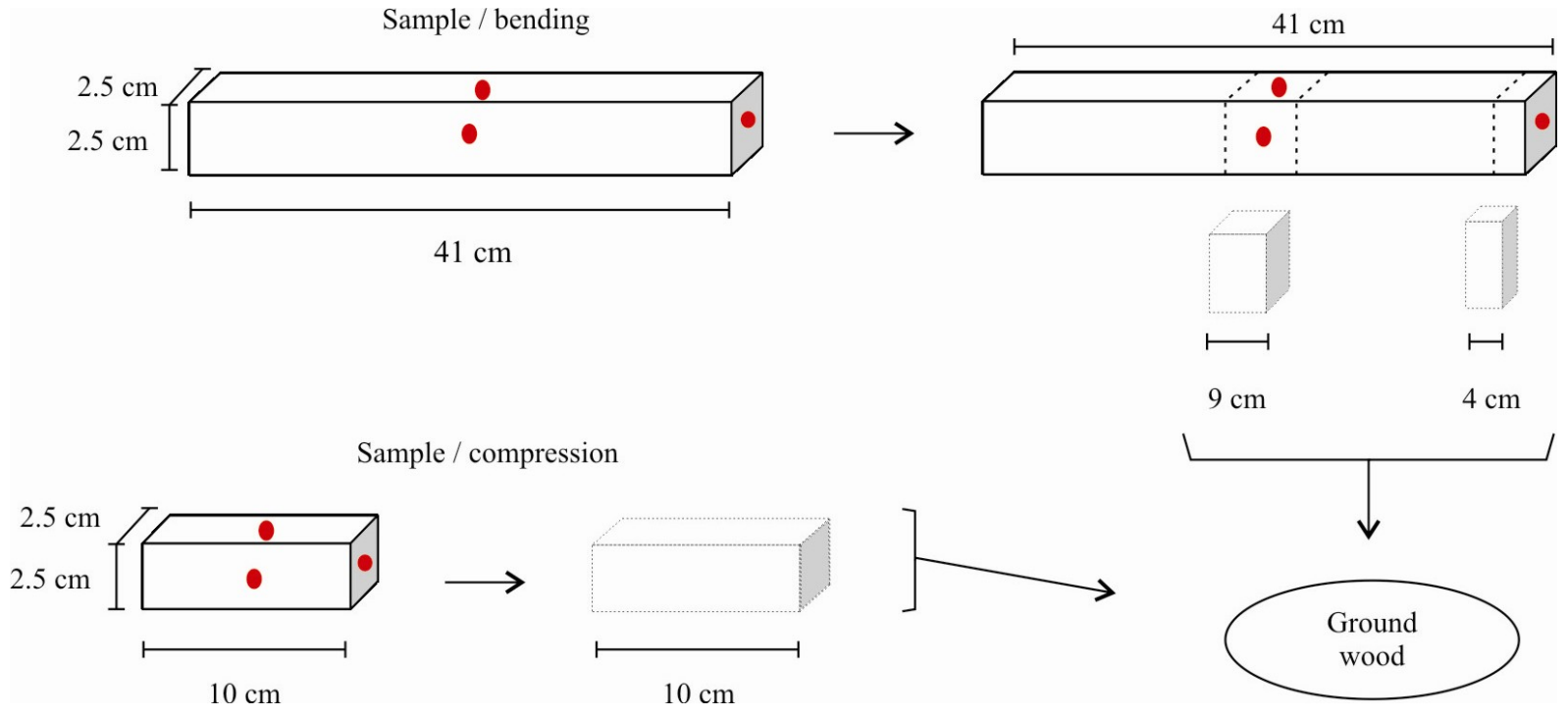

Figure 1 - Points of spectral acquisition in solid wood and portions used for ground wood readings.

Figura 1 - Pontos de aquisição espectral na madeira sólida e regiões utilizadas para a obtenção da madeira moída.

Cerne, Lavras, v. 16, n. 3, p. 291-298, jul./set. 2010 
Table 1 - Results of compression parallel to grain and static bending tests.

Tabela 1 - Ensaio de compressão paralela às fibras e flexão estática.

\begin{tabular}{lccccccc}
\hline Test type & Prop. & Mean $(\mathrm{MPa})$ & $\mathrm{Sd}$ & Min $(\mathrm{MPa})$ & $\mathrm{Max}(\mathrm{MPa})$ & $\mathrm{n}$ \\
\hline \multirow{2}{*}{ Compression parallel to grain } & MOE & 7934.0 & 1466.7 & 5388.3 & 10794.3 & 25 \\
& $\mathrm{CS}$ & 52.1 & 6.9 & 40.1 & 63.6 & 25 \\
\hline \multirow{2}{*}{ Static bending } & MOE & 15972.2 & 2751.1 & 11054.4 & 20178.1 & 19 \\
& MOR & 94.4 & 15.4 & 69.9 & 115.8 & 19
\end{tabular}

MOE - Modulus of elasticity; CS - Strength in compression parallel to grain; MOR - Modulus of rupture; Prop.- Property; $\mathrm{Sd}$ - Standard deviation; Min - Minimum; Max - Maximum; $\mathrm{n}$ - Number of samples.

Values shown in Table 1 for modulus of elasticity, strength in compression parallel to grain and modulus of rupture are similar to results found by Hein et al. (2009), who obtained $7848 \mathrm{MPa}$ for modulus of elasticity in compression parallel to grain testing while investigating Eucalyptus grandis and E. urophylla at age 6.5 years. Silva et al. (2005) worked with Eucalyptus grandis at different ages and obtained $129230 \mathrm{kgf} / \mathrm{cm}^{2}$ (equivalent to $12673 \mathrm{MPa}$ ) as means of modulus of elasticity in static bending testing. Cruz et al. (2003) assessed Eucalyptus clones at age 5.5 to 10.5 years and obtained $15044 \mathrm{MPa}$ as mean of modulus of elasticity in static bending testing, and $7657 \mathrm{MPa}$ as mean of modulus of elasticity in compression parallel to grain testing.

\subsection{Calibration of mechanical properties of wood}

Cell exposure in wood will differ depending on the face being assessed-radial ( $\mathrm{Rd}$ ), tangential (Tg) or transverse (Tr). It is thus expected, for instance, that the greater exposure of parenchyma cells on the radial face will produce different spectral information, and this information in turn can correlate positively or negatively with mechanical properties of wood (HEIN et al. 2009). Based on this information, solid wood calibrations included all 3 faces-radial $(\mathrm{Rd})$, tangential $(\mathrm{Tg})$ and transverse (Tr)-, then an average spectral value of all three faces was worked out (mean), followed by new calibrations.

Table 2 summarizes best calibration results for mechanical properties of wood based on spectral information read on the radial, tangential and transverse faces of solid wood, in addition to spectral means.

Results of cross validation correlation are similar to those found by Hein et al. (2009), who worked with Eucalyptus grandis and E. urophylla clones at age 6.5 years and reported a coefficient of determination $\left(\mathrm{R}^{2}\right)$ of 0.75 in cross validation for modulus of elasticity (MOE) in compression parallel testing.

For strength in compression parallel (CS), the model presented a $\mathrm{R}_{\mathrm{p}}^{2}$ of 0.73 in cross validation. In static bending testing, the best observed values for modulus of elasticity were $\mathrm{r}=0.91$ and $\mathrm{RPD}=2.5$, using tangential face spectra. The best observed values for modulus of rupture was the spectral mean of all three faces, with values $r=0.75$ and $R P D=1.5$. So et al. (2002) obtained good calibrations to estimate modulus of elasticity $\left(\mathrm{R}^{2}=0.87\right)$ while performing bending tests in wood from Pinus taeda L. at ages 15 to 55 years.

As regards use of pretreatments, best correlations were obtained when original spectra were used, except for compressive strength which had its best observed value when multiplicative signal correction was applied. Overall, best correlation values for compression parallel testing were obtained when using transverse face spectra, followed by tangential face and then radial face spectra. As for bending testing, best responses were observed when using tangential face spectra, followed by transverse face and then radial face.

Differences in spectral information depending on the face measured-whether the radial, tangential or transverse section-are yet to be better established (HEIN et al. 2009). Fujimoto et al. (2008) used spectral information from tangential ( $\mathrm{R}^{2}$ between 0.61 and 0.84$)$ and radial $\left(\mathrm{R}^{2}\right.$ between 0.73 and 0.89 ) faces to estimate mechanical properties of two species of genus Larix and concluded that both spectra present the same overall tendency as to calibration. It should be noted that in this particular work calibrations for mechanical properties were based on a small number of samples (n), and also that new studies should be undertaken to investigate the influence of 
Table 2 - Summary of NIRS calibrations for mechanical properties in solid wood.

Tabela 2 - Resumo das calibrações NIRS para as propriedades mecânicas da madeira sólida.

\begin{tabular}{|c|c|c|c|c|c|c|c|c|c|c|}
\hline Wood & Test type & Face & Prop & Treat & $\mathrm{r}$ & LV & Outlier & SECV & RPD & $\mathrm{n}$ \\
\hline \multirow{16}{*}{ Solid } & \multirow{8}{*}{ Comp. } & \multirow{2}{*}{$\mathrm{Rd}$} & MOE & $2 d$ & 0.72 & 3 & 0 & 996.4 & 1.5 & 25 \\
\hline & & & $\mathrm{CS}$ & $1 d$ & 0.74 & 5 & 0 & 4.5 & 1.5 & 25 \\
\hline & & \multirow{2}{*}{$\mathrm{Tg}$} & MOE & $1 d$ & 0.74 & 6 & 0 & 962.9 & 1.5 & 25 \\
\hline & & & CS & $1 d$ & 0.77 & 6 & 0 & 4.3 & 1.6 & 25 \\
\hline & & \multirow{2}{*}{$\operatorname{Tr}$} & MOE & osd & 0.91 & 3 & 0 & 566.2 & 2.6 & 25 \\
\hline & & & CS & osd & 0.89 & 5 & 0 & 3.1 & 2.2 & 25 \\
\hline & & \multirow{2}{*}{ Mean } & MOE & osd & 0.89 & 3 & 0 & 648.3 & 2.3 & 25 \\
\hline & & & CS & MSC & 0.90 & 10 & 0 & 2.8 & 2.5 & 25 \\
\hline & \multirow{8}{*}{ Bending } & \multirow{2}{*}{$\mathrm{Rd}$} & MOE & $1 d$ & 0.71 & 1 & 0 & 1879.7 & 1.5 & 19 \\
\hline & & & MOR & osd & 0.44 & 1 & 0 & 13.6 & 1.1 & 19 \\
\hline & & \multirow{2}{*}{$\mathrm{Tg}$} & MOE & osd & 0.91 & 10 & 0 & 1099.9 & 2.5 & 19 \\
\hline & & & MOR & MSC & 0.74 & 6 & 0 & 10.6 & 1.5 & 19 \\
\hline & & \multirow{2}{*}{$\operatorname{Tr}$} & MOE & $1 d$ & 0.77 & 6 & 0 & 1764.1 & 1.6 & 19 \\
\hline & & & MOR & MSC & 0.65 & 10 & 0 & 13.0 & 1.2 & 19 \\
\hline & & \multirow{2}{*}{ Mean } & MOE & $1 d$ & 0.78 & 6 & 0 & 1680.2 & 1.6 & 19 \\
\hline & & & MOR & osd & 0.75 & 6 & 0 & 10.4 & 1.5 & 19 \\
\hline
\end{tabular}

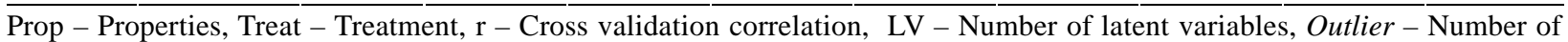
discarded samples, SECV - Standard error of cross validation, RPD - Ratio of performance deviation, $\mathrm{n}$ - Total number of samples used, Comp. - Compression parallel to grain, Rd -Radial, Tg - Tangential, Tr - Transverse, Mean - Spectral mean of 3 faces, MOE - Modulus of elasticity, CS - Strength in compression parallel to grain, MOR - Modulus of rupture, osd - Original spectral data, $1 \mathrm{~d}$ - First derivative, $2 \mathrm{~d}$ - Second derivative, MSC - Multiplicative signal correction.

spectra depending on the face measured, preferably with a larger number of samples and ensuring grain orientation is well defined throughout.

Figure 2 provides a correlation graph between estimated and measured modulus of elasticity in compression parallel to grain testing on the transverse face. There is a strong association between observed and predicted values, indicating the use potential of NIRS to estimate modulus of elasticity from solid wood.

Table 3 summarizes best calibration results for mechanical properties using ground wood spectra.

It was noted that modulus of elasticity in compression parallel testing presents the best value of cross validation correlation, with $r=0.87$ and $R P D=2$. Modulus of elasticity also presents the same number of latent variables and Outlier in both tests, compression and bending, $\mathrm{LV}=3$ and Outlier $=1$.
First and second derivative pretreatments provided the best correlation values overall. According to Schimleck et al. (2003), a RPD value higher than 1.5 is considered satisfactory for preliminary readings and predictions (screenings), and for tree selection in forest improvement programs.

According to Tables 2 and 3, it can be said that calibrations obtained from solid wood spectra were slightly higher than calibrations obtained from ground wood spectra, considering both tests and each of the three properties being tested-MOE, CS and MOR.

Cross validation correlations for mechanical properties using solid wood spectra and ground wood spectra overall presented positive values. However, these values can be improved if in future works a larger number of samples is included in the calibration lot.

Cerne, Lavras, v. 16, n. 3, p. 291-298, jul./set. 2010 


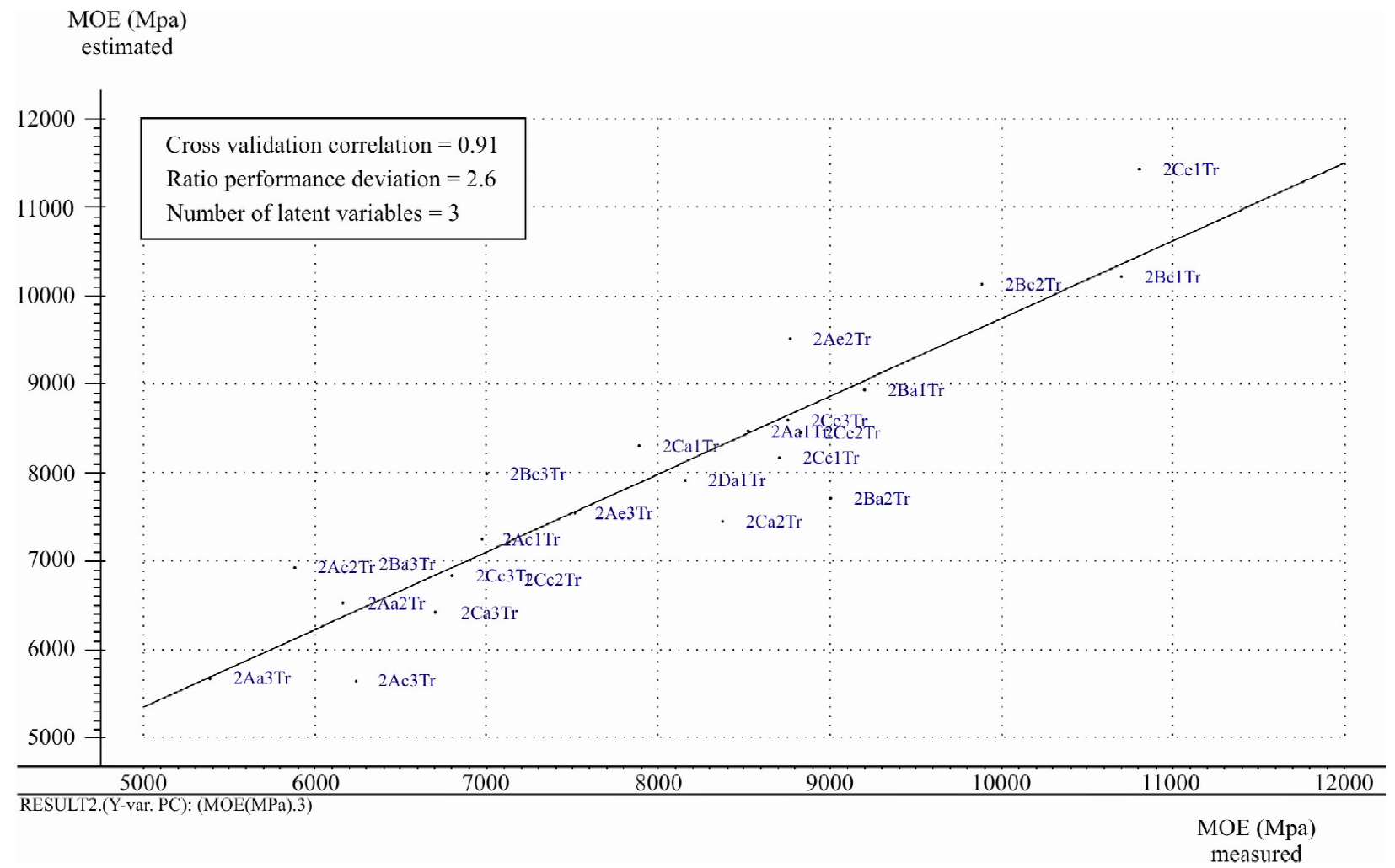

Figure 2 - Correlation graph between estimated and measured modulus of elasticity in compression parallel to grain testing on transverse face.

Figura 2 - Gráfico da correlação entre o módulo de elasticidade estimado e o medido no ensaio de compressão paralela às fibras, face transversal.

Table 3 - Summary of NIRS calibrations for mechanical properties in ground wood.

Tabela 3 - Resumo das calibrações NIRS para as propriedades mecânicas da madeira moída.

\begin{tabular}{|c|c|c|c|c|c|c|c|c|c|}
\hline Wood & Test type & Prop & Treat & $\mathrm{r}$ & LV & Outlier & SECV & RPD & $\mathrm{n}$ \\
\hline \multirow{4}{*}{ Ground } & \multirow{2}{*}{ Comp. } & MOE & $2 d$ & 0.82 & 3 & 1 & 866.3 & 1.7 & 25 \\
\hline & & $\mathrm{CS}$ & $1 d$ & 0.89 & 4 & 0 & 3.0 & 2.3 & 25 \\
\hline & \multirow{2}{*}{ Bending } & MOE & $1 d$ & 0.87 & 3 & 1 & 1346.6 & 2.0 & 19 \\
\hline & & MOR & $1 d$ & 0.72 & 5 & 0 & 10.7 & 1.4 & 19 \\
\hline
\end{tabular}

Prop - Property, Treat - Treatment, $\mathrm{r}$ - Cross validation correlation, LV - Number of latent variables, Outlier - Number of discarded samples, SECV - Standard error of cross validation, RPD - Ratio of performance deviation, $n$ - Total number of samples used, Comp. - Compression parallel to grain, MOE - Modulus of elasticity, CS - Strength in compression parallel to grain, MOR - Modulus of rupture, $1 \mathrm{~d}$ - First derivative, $2 \mathrm{~d}$ - Second derivative.

\section{CONCLUSIONS}

Best correlation coefficients to estimate modulus of elasticity and compressive strength, in compression parallel to grain testing, were obtained when using original spectra from solid wood.
Modulus of elasticity in static bending testing was best estimated when solid wood spectra were subjected to first derivative treatment, while modulus of rupture presented best calibrations when original spectra were used.

\section{Cerne, Lavras, v. 16, n. 3, p. 291-298, jul./set. 2010}


As for ground wood spectra, higher values of cross validation correlation were obtained when using first and second derivative pretreatments than when using original spectra.

\section{ACKNOWLEDGMENTS}

The authors wish to thank V\&M Florestal for providing technical and financial support, and the Federal University of Lavras for providing laboratory facilities to carry out tests.

\section{BIBLIOGRAPHICAL REFERENCES}

BAILLÈRES, H.; DAVRIEUX, F.; HAM-PICHAVANT, F. Near infrared analysis as a tool for rapid screening of some major wood characteristics in a eucalyptus breeding program. Annals of Forest Science, Les Ulis, v. 59, n. 5/6, p. 479-490, July/Oct. 2002.

CRUZ, C. R.; LIMA, J. T.; MUNIZ, G. I. B. Variações dentro das árvores e entre clones das propriedades físicas e mecânicas da madeira de híbridos de Eucalyptus. Scientia Forestalis, Piracicaba, v. 64, n. 1, p. 33-47, dez. 2003.

FUJIMOTO, T.; KURATA, Y.; MATSUMOTO, K.; TSUCHIKAWA, S. Application of near infrared spectroscopy for estimating wood mechanical properties of small clear and full length lumber specimens. Journal of Near Infrared Spectroscopy, Sussex, v. 16, n. 6, p. 529-537, 2008.

GELADI, P.; KOWALSKI, B. R. Partial least-squares regression: a tutorial. Annales de Chimie Analytique et de Chimie Appliquee, Paris, v. 185, n. 1, p. 1-17, Jan. 1986.

GREEN, D. W.; WINANDY, J. E.; KRETSCHMANN, D. E. Mechanical properties of wood. In: Wood handbook: wood as an engineering material. Madison: Department of Agriculture, Forest Service, Forest Products Laboratory, 1999. chap. 4, p. 76-120.

HEIN, P. R. G.; CAMPOS, A. C. M.; LIMA, J. T.; TRUGILHO, P. F.; CHAIS, G. Estimativa da resistência e da elasticidade à compressão paralela às fibras da madeira de Eucalyptus grandis e E. urophylla usando a espectroscopia no infravermelho próximo. Scientia Forestalis, Piracicaba, v. 37, n. 82, p. 119-129, jun. 2009.

HEIN, P. R. G. Multivariate regression methods for estimating basic density in Eucalyptus wood from near infrared spectroscopic data. Cerne, Lavras, v. 16, Suplemento, p. 90-96, jul. 2010.
KELLEY, S. S.; RIALS, T. G.; GROOM, L. R.; SO, C. L. Use of near infrared spectroscopy to predict the mechanical properties of six softwoods. Holzforschung, Berlin, v. 58, n. 3, p. 252-260, May/June 2004.

KLOCK, U. Qualidade da madeira juvenil de Pinus maximino H. E. Moore. 2000. 275 p. Tese (Doutorado em Ciências Florestais) - Universidade Federal do Paraná, Curitiba, 2000.

KOllmann, F. F. P.; CÔTÉ JUNIOR, W. A. Principles of wood science and technology: solid wood. Berlin: SpringerVerlag, 1968. v. 1, 592 p.

MARTENS, H.; NAES, T. Multivariate calibration. New York: Wiley, 1996. $155 \mathrm{p}$.

PASQUINI, C. Near infrared spectroscopy: fundamentals, practical aspects and analytical applications. Journal of the Brazilian Chemical Society, São Paulo, v. 14, n. 2, p. 198-219, mar./abr. 2003.

RIBEIRO, P. G. Utilização de técnicas alternativas para caracterização tecnológica de madeiras. 2009. 108 p. Dissertação (Mestrado em Engenharia Florestal) - Universidade de Brasília, Brasília, 2009.

SAVITZKY, A.; GOLAY, M. J. E. Smoothing and differentiation of data by simplified least-squares procedures. Analytical Chemistry, Washington, v. 36, n. 8, p. 1627-1639, Apr. 1964.

SCHIMLECK, L. R.; DORAN, J. C.; RIMBAWANTO, A. Near infrared spectroscopy for cost-effective screening of foliar oil characteristics in a Melaleuca cajuputi breeding population. Journal of Agricultural and Food Chemistry, Easton, v. 51, n. 9, p. 2433-2437, May 2003.

SCHIMLECK, L. R.; MICHELL, A. J.; RAYMOND, C. A.; MUNERI, A. Estimation of basic density of Eucalyptus globulus using Near-Infrared Spectroscopy. Canadian Journal of Forest Research, Ottawa, v. 29, n. 2, p. 194-201, Feb. 1999.

SIESLER, H. W.; OZAKI, Y.; KAWATA, S.; HEISE, H. M. Near infrared spectrscopy: principles, instruments, applications. New York: Wiley-VCH, 2002. 360 p.

SILVA, J. de C.; MATOS, J. L. M. de; OLIVEIRA, J. T. da S.; EVANGELISTA, W. V. Influência da idade e da posição radial na flexão estática da madeira de Eucalyptus grandis Hill ex. Maiden. Revista Árvore, Viçosa, v. 29, n. 5, out. 2005.

Cerne, Lavras, v. 16, n. 3, p. 291-298, jul./set. 2010 
SOTELO, F. F. Aplicação da espectroscopia de infravermelho próximo na caracterização de petróleo: simulação de uma unidade de destilação atmosférica. 2006. 154 p. Tese (Doutorado em Engenharia Química) - Universidade de São Paulo, São Paulo, 2006.

THUMM, A.; MEDER, R. Stiffness prediction of radiata pine clearwood test pieces using near infrared spectroscopy. Journal of Near Infrared Spectroscopy, Sussex, v. 9, n. 2, p. 117-122, 2001 .

VIANA, L. C.; TRUGILHO, P. F.; HEIN, P. R. G.; LIMA, J. T.; SILVA, J. R. M. da. Predicting the morphological characteristics and basic density of Eucalyptus wood using the NIRS technique. Cerne, Lavras, v. 15, n. 4, p. 421-429, out./dez. 2009.

Cerne, Lavras, v. 16, n. 3, p. 291-298, jul./set. 2010 